\title{
Risk management model development by integrating House of Risk model and ANP model
}

\author{
Christine Natalia ${ }^{1 *}$, Chendrasari Wahyu Oktavia ${ }^{2}$, Trifenaus Prabu Hidayat ${ }^{3}$, Welhelmina Makatita ${ }^{4}$ \\ 1, 3,4 Industrial Engineering Department, Atma Jaya Catholic University of Indonesia, Jakarta, Indonesia \\ ${ }^{2}$ Industrial Engineering Department, Wijaya Putra University, East Java, Indonesia
}

\author{
Keywords \\ Supply chain \\ Risk management \\ Risk events \\ Risk causes \\ House of Risk (HOR) \\ Analytic Network Process (ANP) \\ Alternative action
}

Received: 10 March 2020

Accepted: 20 May 2020

Published: 12 August 2020

\begin{abstract}
In this study, the supply chain risk management model will be integrated using HOR and ANP model. HOR phase 1 is used to determine which risk agent will be prioritized in advance for precautionary measures and ANP to obtain the best alternative action. ANP is a tool to determine the correlation between risk mitigation and hence rank that mitigation based on the priorities. The second phase of HOR determines the correlation between risk mitigation and the event risk and its effectiveness based on its degree of difficulty to be applied. This study is conducted on 3 reputable manufacturing industries to be compared and analyzed. HOR2 is intended to prioritize the proactive actions that the company should pursue to maximize the cost-effectiveness of the effort in dealing with the selected risk agents in HOR 1. This research shows that risks apply differently to each company. Hence, the ANP ranking is different. Mitigation risk's rank is determined from the second phase of HOR as it has considered the correlation aspect of risk agents and its degree of difficulty to be mitigated. Finally, special actions are applied to various risks, such as performance appraisal to the staff. Further study is needed, such as by ISM method in order to make mitigation actions are focused on the companies.
\end{abstract}

(C) 2020 The Author(s). Published by TAF Publishing.

\section{INTRODUCTION}

As the manufacturing industry grows, consumer demand is increasingly varied. So that readiness in facing changes in demand has resulted in increased complexity of business processes in the manufacturing industry. To maintain it must be balanced with good Supply Chain Management. As stated by Wibisono (2006) corporate strategy is a pattern or plan that integrates key objectives or company policies with a series of actions in a mutually binding statement. So it can be concluded that strategy is one of the keys for a company to have added value for the company itself. A supply chain can be defined as a network consisting of several companies (including suppliers, manufacturers, distributors and retailers) that work together and are involved both directly and indirectly in meeting customer demand, where these companies carry out material procurement functions, transformation processes material into semi-finished products and finished products, and distri- bution of finished products to end customers (Bernik, Azis, Kartini, \& Harsanto, 2015; Pujawan \& Geraldin, 2009; Piyachat, 2017; Phungphol, Tumad, Sangnin, \& Pooripakdee, 2018). The objectives of supply chain management are to meet customer needs, reduce costs, increase revenue, and make the company stronger. To fulfill all the objectives of supply chain management in the company, management of supply chain management is needed that is good and directed.

In running a good and directed supply chain management, it cannot be separated from risk. Risks can be present in various forms and the arrival of risks cannot be ascertained, so that risk can be said to be unpredictable. The definition of risk is something that might occur to stop activities or interfere with ongoing activities (Waters, 2011). According to Pujawan and Mahendrawathi (2010), supply chain risk starts to arise when the supply chain begins to operate. This risk can be in the form of scheduling, technology, payment,

${ }^{*}$ corresponding author: Christine Natalia

†email: chrisnatalia@atmajaya.ac.id 
distribution, even cost uncertainty in the supply chain. Supply chain risk according to Sinha, Whitman, and Malzahn (2004) is the uncertainty of the occurrence of an event that can be one or several pairs or networks in the supply chain and can affect (generally in a negative sense) the achievement of business objectives.

Several studies have been carried out regarding risks in the company's supply chain. Risks can be found in suppliers and their impact on order and distribution policies on companies (Kull \& Closs, 2008). The model for mitigating supplier risk has also been done using the Failure Mode Effect Analysis (FMEA) approach as a continuous improvement step in the aviation industry (Saaty, 1996). Each risk is assessed based on 2 indicators, namely occurrence and severity. The model for mitigating supply chain risk was also developed by Norrman and (Norrman \& Jansson, 2004) in the telephone industry with a close-loop system consisting of identification, grouping, prevention/mitigation and control. Other research was also carried out by Kleindorfer and Saad (2005) with 3 general processes, namely looking for root causes of risk, valuation/weighting of risks and mitigation. A more applicable or real approach is carried out by Ketikidis, Koh, Gunasekaran, Cucchiella, and Gastaldi (2006) with 6 steps in the model that is made, namely analysis of the supply chain process, identifying problems, describing the risks posed by these problems, controlling risks, finding sufficient real options to mitigate risks and implement it. There are 10 categories that are described as variables from real options. Analytical Hierarchy Process (AHP) is used to assess the risks that occur in the company by Gaudenzi and Borghesi (2006) with steps namely prioritizing objects from the supply chain, identifying indicators of risk events and evaluating potential negative impacts. All of the above studies have similar processes to the research that will be carried out, but have a gap in the assessment of risk risks, namely the HOR method to assess and rank each risk and ANP to link each mitigation action qualitatively but converted into certain scales.

Based on previous studies that have been done in looking at and analyzing risk mitigation that occur in the company, the most widely used method is the HOR method, because indeed this method is quite flexible and is divided into 2 types namely HOR 1 and HOR 2 . Where each the part is used to answer the important thing, namely HOR 1 to find out the risks that occur in the company and HOR 2 determines the first action/activity to be carried out, considering the differences effectively such as involvement and the level of difficulty in its implementation. Some previous studies carried out generally only used the HOR method. The disadvantage of the implementation of the HOR method is that the risk mitigation carried out is not known to be related to one another so that in the use of the HOR method, all risk mitigation is carried out in accordance with the order of actions of effectiveness and efficiency. Therefore, the Analytcial Network Process (ANP) method is needed. ANP is a method that produces a framework to overcome the problem of decision making using the concept of mutual influence. The use of the ANP method in research is to get risk mitigation priorities based on the relationship between risk mitigation. From the priority relationship, some risk mitigation will be eliminated. The results of risk mitigation elimination will then be calculated using the phase 2 HOR method. In some previous studies, calculation of risk has been carried out using the HOR and ANP methods but did not proceed with the phase 2 HOR calculation.

Each company has different risk events, all of which are caused by the diversity of demands faced by each industry. Therefore this research takes 3 companies engaged in manufacturing and have different products but have almost the same risk to obtain supply chain risk mitigation by each industry.

\section{LITERATURE REVIEW \\ Risk}

According to Tang (2006), risk can have an impact on the company's performance in the short term and if the risk is not managed properly it will cause the company to go out of business. Based on this, risk management is considered very important so that steps need to be taken starting from identifying risks, the causes of risk, the impact of a risk, and the probability of occurrence of risk events.

Based on an understanding of risk, (Tang, 2006) categorizes risks as follows:

1. Operational risk is uncertainty originating in the supply chain which consists of uncertainty in demand, supply and costs.

2. Risk of disruption is a risk due to large-scale disturbances caused by nature (such as earthquakes, storms, terrorist attacks, floods, etc.) and humans (such as the monetary crisis).

From the explanation above, it can be concluded that risk is one of the things that has a major influence on a company. Therefore, important risk management is done to minimize losses to the company.

\section{Risk Management}

Risk management is an activity to know, analyze, and control every risk that occurs in activities that occur in a com- 
pany with the aim of obtaining higher effectiveness and ef- $\quad$ 31000: 2009:

ficiency (Darmawi, 2008).

Below is a risk management framework according to ISO

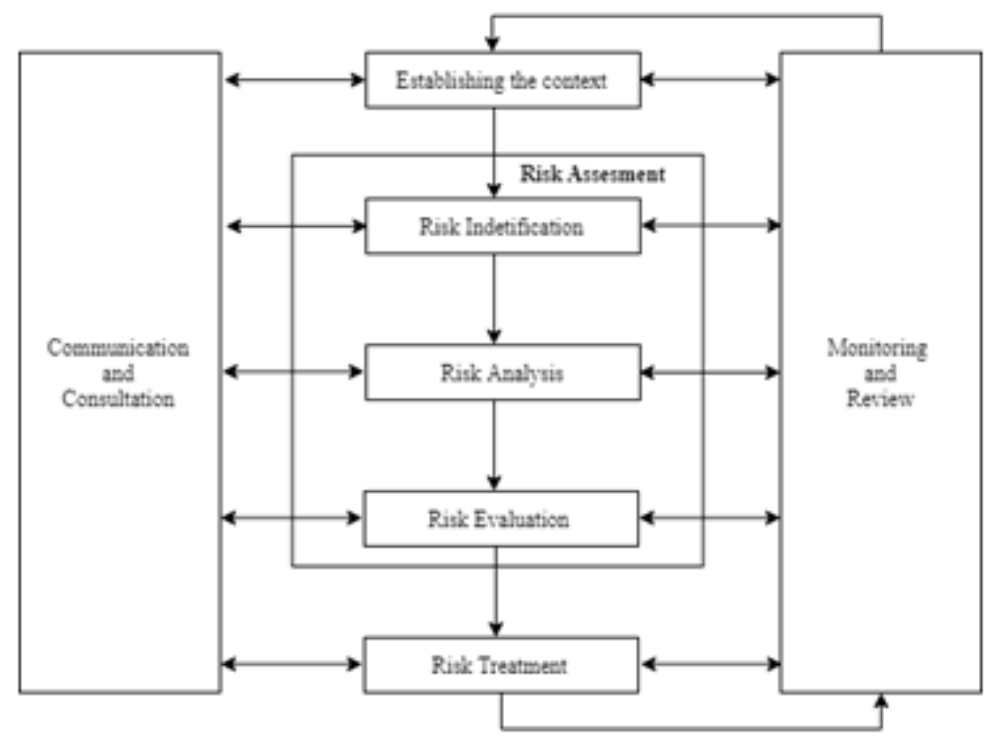

FIGURE 1. Risk management process (Sorce: ISO:31000:2009)

The risk management process according to the above framework is:

1. Determination of context, to identify and reveal organizational goals, the environment in which it wants to be achieved.

2. Risk assessment consisting of:

a. Risk identification, is done by recording what risks occur in the company.

b. Risk analysis, carried out by analyzing the possibility and impact of identified risks.

c. Risk evaluation, carried out by comparing risk analysis with risk criteria that have been previously set.

3. Risk management which consists of:

a. Avoid risk

b. Risk mitigation

c. Risk transfer

d. Accept risk

\section{Supply Chain Risk Management Mitigation Strategy}

Risk mitigation is one way to minimize the risks that occur. Actions taken to mitigate risk in the company must be planned in advance by the company, made in writing and then known by the division manager who will handle the risk. According to Tang (2006), there are four approaches to mitigating risk. This approach is supply management, product management, demand management, and information management. The four approaches will then improve the operations that apply to the supply chain by coordinating as follows:

1. Companies can coordinate and collaborate with partner up streams to ensure efficiency in material supply throughout the supply chain.

2. Companies can coordinate and collaborate with downstream partners by influencing demand in a profitable manner. 3. Companies can modify products or design processes so as to facilitate meeting demand and supply.

4. Companies can improve coordination and collaboration if they can access various types of information available on supply chain partners.

\section{Supply Chain Operation Reference (SCOR)}

There are five scope of the Pujawan and Mahendrawathi (2010) SCOR process, namely:

1. Plan

Is a process related to the balance of demand and supply to meet the needs in the fields of procurement, production, and shipping. The Process Plan covers distribution needs, planning in the fields of production, material, capacity, and planning control.

2. Source

Is the process of procuring goods and services to meet customer demand. The Source process includes activities for scheduling, receiving, checking, selecting, and performing supplier performance. 
3. Make

Is a process that is carried out to change raw materials into products desired by customers. Activities contained therein are production scheduling activities, production activities themselves, activities related to product quality, product management activities, and maintenance activities of production facilities.

4. Deliver

Is a process that is carried out to be able to meet customer demand in the form of goods and services. The activities contained in the deliveries process are handling orders from customers, selecting shipping services, finished material warehousing, and sending bills to customers.

\section{Return}

Is the process of returning or receiving a product for reasons that can be tolerated. The activities contained therein are identifying the condition of the product, and returning the product by scheduling product returns first.

\section{HOR}

HOR is a model in supply chain risk management using the House of Quality and FMEA approach to manage supply chain risk (Pujawan \& Geraldin, 2009). This approach focuses on preventive actions from the risks that occur and helps to reduce the possibility of the occurrence of risk agents. So, reducing risk agents means reducing the incidence of several risk events.

HOR is a model in supply chain risk management using the House of Quality and FMEA approach to manage supply chain risk (Pujawan \& Geraldin, 2009). This approach focuses on preventive actions from the risks that occur and helps to reduce the possibility of the occurrence of risk agents. So, reducing risk agents means reducing the incidence of several risk events. The HOR 1 framework is carried out to determine which risk agents are given priority in further risk prevention (Rizqiah, 2017).

After obtaining the priority order of risk agents that will be carried out corrective/preventive actions, then the second stage is HOR 2. The framework for the stages of HOR 2 can be seen in the following table.

TABLE 1. HOR 1 framework

\begin{tabular}{|c|c|c|c|c|c|c|c|c|c|}
\hline Business Processes & Risk Event (Ei) & $\mathbf{A 1}$ & $\mathbf{A 2}$ & A3 & A4 & A5 & A6 & A7 & Severity of Risk Event i (Si) \\
\hline \multirow[t]{2}{*}{ Plan } & E1 & R11 & R12 & R13 & & & & & S1 \\
\hline & E2 & $\mathrm{R} 23$ & & & & & & & S2 \\
\hline \multirow[t]{2}{*}{ Source } & E3 & $\mathrm{R} 33$ & & & & & & & S3 \\
\hline & E4 & $\mathrm{R} 43$ & & & & & & & S4 \\
\hline \multirow[t]{2}{*}{ Make } & E5 & & & & & & & & S5 \\
\hline & E6 & & & & & & & & S6 \\
\hline Occurrence of agent $\mathrm{j}$ & 01 & 02 & 03 & 04 & 05 & 06 & 07 & & \\
\hline $\mathrm{ARP} j$ & ARP1 & ARP2 & ARP3 & ARP4 & ARP5 & ARP6 & ARP7 & & \\
\hline Priority rank of agent $\mathrm{j}$ & & & & & & & & & \\
\hline
\end{tabular}

(Source: (Pujawan \& Geraldin, 2009) 
TABLE 2. HOR 1 framework

\begin{tabular}{lllllll}
\hline \hline \multicolumn{3}{c}{ Preventive action (PAi) } & & \\
\hline To be Treated Risk Agent (Aj) & PA1 & PA2 & PA3 & PA4 & PA5 & Aggregate Risk Potensials (ARPi) \\
\hline A1 & E11 & & & & & ARP1 \\
A2 & & & & & & ARP2 \\
A3 & & & & & & ARP3 \\
A4 & & & & & & ARP4 \\
Total effectiveness of action k & TE1 & TE2 & TE3 & TE4 & TE5 & \\
Degree of difficulty performing action k & D1 & D2 & D3 & D4 & D5 & \\
Effectiveness to difficulty ratio & ETD1 & ETD2 & ETD3 & ETD4 & ETD5 & \\
Rank of priority & R1 & R2 & R3 & R4 & R5| & \\
\hline \hline
\end{tabular}

(Source: (Pujawan \& Geraldin, 2009)

\section{ANP}

The ANP method is the development of the AHP method. The ANP method is able to correct AHP weaknesses in the form of the ability to accommodate the interrelationships between criteria or alternatives (Saaty, 1996).

Inside the ANP there are 2 controls that need to be considered in modeling the system that you want to know the weight of. The first control is a hierarchy control that shows the relevance of the criteria and sub-criteria. In this control does not require a hierarchical structure as in the AHP method. Other controls are control relationships that indicate the existence of interrelationships between criteria or clusters (Saaty, 1996).

In Saaty (1996), it also explains the technical analysis of ANP by using pairwaise comparison on alternatives and project criteria. In AHP networks there are levels of goals, criteria, subcriteria, and alternatives, each of which has an element. Whereas in the ANP network, the level in the AHP is called a cluster that can have criteria and alternatives in it. ANP has a supermatric that will automatically produce the right weight for the criteria and alternatives if the data used is the priority vector on the supermatrix. This is a simple method because it does not require thinking per section on the user. Only knowing the data and supermarkets will produce priority at each point in the model (Saaty, 1996).

\section{RESEARCH METODOLOGY}

The HOR method is a method developed by Pujawan and Geraldin (2009). Pujawan and Geraldin (2009) integrated the FMEA model and HOQ (House of Quality) mode. This integration later became the development of the HOR model. The purpose of developing this model is to help mitigate risk based on the causes of risk found in research so that it can help minimize the risks that occur in the company. In this method, the first mapping of the company's business processes into 5 SCOR scope is planned, namely plan, make, source, delivery, and return. After the mapping process is carried out, the process of identifying risks and causes of risk is carried out. Risks and causes of risk that have been identified, then given an assessment of the risks and causes of risk based on the severity, assurance, and level of correlation. Both Severity, assurance, and the level of correlation use different scales, for Severity and assurance using a scale of 1-10 and the level of correlation using a scale of $0,1,3$ and 9. These three factors are used to calculate the ARP value. ARP is known as the ARP, where the ARP value is a reference value to evaluate which risk causes occupy the highest value. With the ARP value possessed by each of the causes of this risk, the causes of this risk can be evaluated. The higher the ARP value, the more risk-related causes must be prioritized for mitigation actions. Risk mitigation is carried out by calculating the correlation between the causes of risk and risk mitigation. In addition, risk mitigation is also carried out by taking into account the degree of difficulty in mitigating risks to the company. from these two calculations, the value of Effectiveness to Difference Culture of Action (ETDk) will be obtained. The order of ETDk values will be the order in which risk mitigation is carried out on the company.

The second method carried out in this study uses the ANP method, the ANP method is a development method of the AHP method where the ANP method already has the ability to capture the interrelationships between reciprocal criteria (Saaty, 1996).

Based on the previous explanation, in this study integration of the HOR and ANP methods will be carried out. Integration will be carried out in the calculation of risk mitigation. the sequence of work on the research outline begins with calculating the risk assessment using the HOR method stage 1. From this calculation, a mapping of risk mitigation is then carried out. Risk mitigation is calculated using the ANP method. From the ANP calculation, risk mitigation will be obtained as a priority because it has a weight related to other risk mitigation. Prioritized risk mitigation is then recalculated using the HOR method phase 2. The end result of 
risk mitigation is a sequence of risk mitigation that are interrelated while considering the relevance of the causes of risk and the degree of difficulty in mitigating risk.

The sequence of work done to determine the risk events, causes of risk, and risk mitigation based on the HOR and Analytical Networking Process methods are as follows:

1. Doing business process mapping in 3 manufacturing industries.

2. Mapping supply chain activities based on business processes for each industry.

3. Conduct direct observation of 3 Limited Liability Companies.

4. Identifying risks by confirming risk on the 3 parties of the company.

5. Conduct risk assessments based on the degree of severity, occurrance, and correlation between causes and risk events. 6. Perform HOR 1 calculations.

7. Obtain the ARP value on the risk cause based on the pareto diagram provisions in the calculation of HOR 1.

8. Conduct observations regarding company risk mitigation.

9. Confirming risk mitigation to the company.

10. Make linkages between risk mitigation.

11. Making a matrix of the ANP.

12. Perform pairwise comparisons and prioritize calculations using the ANP method.
13. Calculate the level of difficulty and the correlation between mitigation and the causes of risk based on selected causes in the results of the ANP priority.

14. Perform calculations of HOR 2.

15. Determine the order of risk mitigation based on the HOR 2 method and evaluate risk mitigation in accordance with what happens in each Industry.

In the third final stage of the risk mitigation observation results produced are compared as supporting results for this study so that the results obtained can answer the objectives of this study.

\section{RESULTS AND DISCUSSION}

This research was conducted at 3 manufacturing companies, namely: a battery manufacturer, a plastic bottle manufacturer, and an industrial gear and mechanical part manufacturer. The following is an example of data analysis using the HOR 1, ANP, and HOR 2 models at battery manufacturer.

\section{HOR 1}

HOR 1 is the initial stage of determining which risk agents are priorities in risk prevention. Previously, prior risk confirmation had been made to the company regarding the risk events and their causes. Table 1 . shows examples of events and causes of risk from the perspective plan in SCOR at these three manufacturer.

TABLE 3. Risk event and risk agent at battery manufacturer

\begin{tabular}{|c|c|c|c|c|}
\hline Company & SCOR & Process & Risk Event & Risk Agent \\
\hline & & $\begin{array}{l}\text { Production Planning } \\
\text { and Control }\end{array}$ & $\begin{array}{l}\text { Mistake on production } \\
\text { planning }\end{array}$ & Wrong forecasting \\
\hline & & & $\begin{array}{l}\text { Scheduling discrep- } \\
\text { ancy }\end{array}$ & Demand shifting \\
\hline & & & $\begin{array}{l}\text { Sudden change on } \\
\text { production plan }\end{array}$ & $\begin{array}{l}\text { Sudden demand on } \\
\text { particular product }\end{array}$ \\
\hline & & $\begin{array}{l}\text { Material Requirement } \\
\text { Planning }\end{array}$ & $\begin{array}{l}\text { Mistake on calculation } \\
\text { of material require- } \\
\text { ment for production }\end{array}$ & $\begin{array}{l}\text { Wrong estimated data } \\
\text { on material require- } \\
\text { ment plan for produc- } \\
\text { tion }\end{array}$ \\
\hline & & Maintenance Planning & $\begin{array}{l}\text { Mistake on main- } \\
\text { tenance schedule } \\
\text { plan for production } \\
\text { machine }\end{array}$ & $\begin{array}{l}\text { Sudden machine } \\
\text { breakdown }\end{array}$ \\
\hline \multirow[t]{4}{*}{ Battery Manufacturer } & Plan & Inventory Control & $\begin{array}{l}\text { late arrival of raw ma- } \\
\text { terials }\end{array}$ & Procurement delay \\
\hline & & Production Activity & $\begin{array}{l}\text { Postponement on pro- } \\
\text { duction process }\end{array}$ & $\begin{array}{l}\text { Maintenanced ma- } \\
\text { chine }\end{array}$ \\
\hline & & & & $\begin{array}{l}\text { Disfunctioned ma- } \\
\text { chine }\end{array}$ \\
\hline & & & Injury at work & Careless workers \\
\hline
\end{tabular}


TABLE 4. Continue...

\begin{tabular}{|c|c|c|c|c|}
\hline Company & SCOR & Process & Risk Event & Risk Agent \\
\hline & & & \multirow{4}{*}{ Not fulfilled demand } & $\begin{array}{l}\text { Disobedient of safety } \\
\text { regulation }\end{array}$ \\
\hline & & & & $\begin{array}{l}\text { Worker's disobedient } \\
\text { on standard opera- } \\
\text { tional procedures }\end{array}$ \\
\hline & & & & $\begin{array}{l}\text { Worker's Low Focus } \\
\text { while working }\end{array}$ \\
\hline & & & & $\begin{array}{l}\text { Fluctuative shifting } \\
\text { demand }\end{array}$ \\
\hline
\end{tabular}

TABLE 4. Risk event and risk agent at plastic bottle manufacturer

\begin{tabular}{|c|c|c|c|c|}
\hline Company & SCOR & Process & Risk Event & Risk Agent \\
\hline \multirow{6}{*}{$\begin{array}{l}\text { Plastic Bottle } \mathrm{M} \\
\text { facturer }\end{array}$} & \multirow{6}{*}{ Plan } & Forecasting & $\begin{array}{l}\text { Uncertain order quan- } \\
\text { tity from buyer }\end{array}$ & No forecast planning \\
\hline & & \multirow[t]{2}{*}{$\begin{array}{l}\text { Raw Material Specifi- } \\
\text { cation Fulfillment }\end{array}$} & \multirow[t]{2}{*}{$\begin{array}{l}\text { Supplier breach con- } \\
\text { tract agreement }\end{array}$} & $\begin{array}{l}\text { Changes on raw mate- } \\
\text { rial or temporary ven- } \\
\text { dor }\end{array}$ \\
\hline & & & & $\begin{array}{l}\text { Bahan baku yang } \\
\text { diterima tidak sesuai } \\
\text { spesifikasi }\end{array}$ \\
\hline & & Financial planning & $\begin{array}{l}\text { Plan differences be- } \\
\text { tween production and } \\
\text { financial }\end{array}$ & No forecast planning \\
\hline & & \multirow[t]{2}{*}{ Production Planning } & $\begin{array}{l}\text { Sudden change on } \\
\text { production plan }\end{array}$ & \\
\hline & & & Wildfire happenned & Accident occurred \\
\hline
\end{tabular}

TABLE 5. Risk event and risk agent at industrial gear and mechanical parts manufacturer

\begin{tabular}{|c|c|c|c|c|}
\hline Company & SCOR & Process & Risk Event & Risk Agent \\
\hline \multirow[t]{3}{*}{ Gear Manufacturer } & Plan & Capacity Planning & $\begin{array}{l}\text { Nonconformity be- } \\
\text { tween capacity plan } \\
\text { and production }\end{array}$ & $\begin{array}{l}\text { Shortage capacity } \\
\text { from the company }\end{array}$ \\
\hline & Production Planning & $\begin{array}{l}\text { Sudden change on } \\
\text { production plan }\end{array}$ & $\begin{array}{l}\text { Company's order pri- } \\
\text { ority }\end{array}$ & \\
\hline & & & & $\begin{array}{l}\text { Shortage on materials } \\
\text { for production }\end{array}$ \\
\hline
\end{tabular}

Based on the value of severity and occurrence, ARP is calculated. ARP calculations require an assessment of the relationship of risk events and causes of risk with the following conditions:

- The value of 0 means there is no link between the risk event and the risk cause.

- Value 1 means a low link between risk events and risk causes.

- Value 3 means moderate linkages between risk events and risk causes.

- A value of 9 means a high link between risk events and risk causes.

Each ARP value is obtained using the formula:

$$
\mathbf{A R P j}=\operatorname{Ojx}[\mathbf{A i}(\mathbf{S i})+\mathbf{A i}(\mathbf{S i})+\ldots+\mathbf{A i}(\mathbf{S i})]
$$

The ARP value obtained is sorted and calculated cumulatively. The calculation results are then used as input for processing using the Pareto diagram to determine which risks are prioritized according to the $80 / 20$ principle. Priority risk is a dangerous risk in the company's supply chain activities. The following are examples of Pareto diagram results from PT. X: 


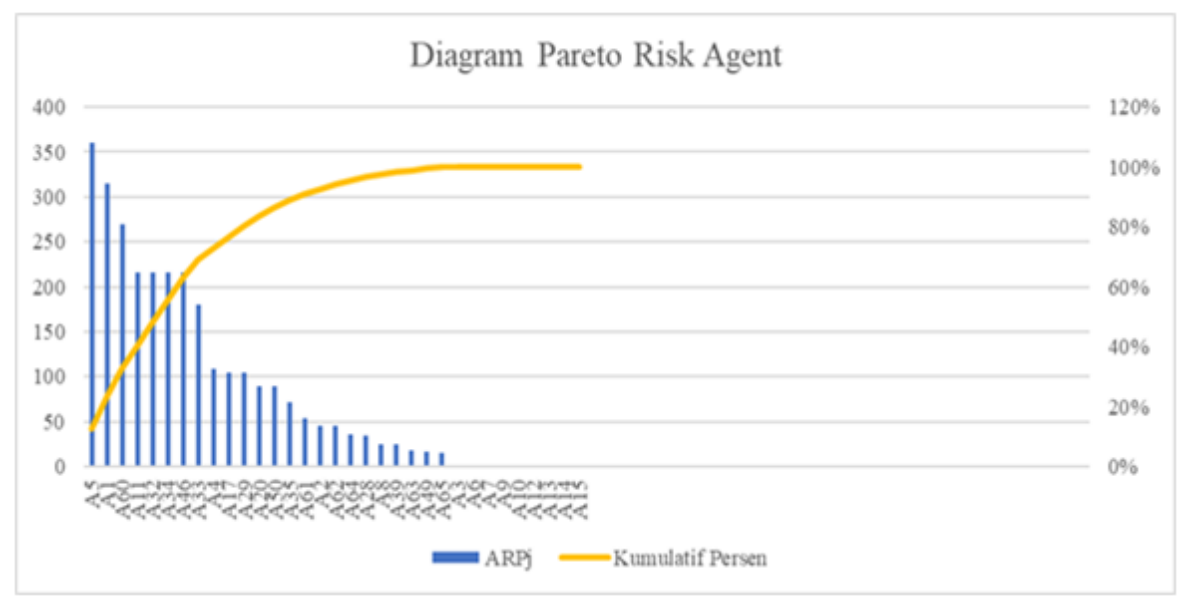

FIGURE 2. Pareto diagram of battery manufacturer

For example, based on the Pareto diagram, the risk agent or the most dangerous cause of risk is an error in information on the estimated data on material requirements in production (A5). In addition, there are several causes of risk that are below $80 \%$ so that the causes of these risks need to be mitigated. The use of the HOR 1 Method is effective in getting the most common causes of risk for all manufacturer. The advantage of the HOR phase 1 method is that it can rank the causes of risk through the ARP based on the causes of risk that most influence the company's performance. Thus the risk causes can be mitigated by using ANP and Phase 2
HOR methods.

The cause of this risk is then put into ANP to determine the risk mitigation that can be carried out by the company. Risk mitigation is based on related journal references and brain storming with the company which is then confirmed by the company.

The linkages of each existing risk mitigation are entered into the Super Decision software to obtain ANP modeling. Super Decision helps determine priority risk mitigation. Cluster is SCOR's scope, namely plan, make, deliver, return consisting of nodes which are risk mitigation.

TABLE 6. Mitigation risk for battery manufacturer

\begin{tabular}{ll}
\hline \hline Code & Preventive Actions \\
\hline PA1 & $\begin{array}{l}\text { Increase practical coordination with } \\
\text { distributor company } \\
\text { Increase the coordination with Cus- } \\
\text { tomer }\end{array}$ \\
Increase the coordination with ware- \\
PA3 & house department \\
& Have an optimal safety stock \\
PA4 & Increase the coordinaton with pur- \\
PA5 & chasing department \\
& 5S Implementation \\
PA6 & Supervise the production process \\
PA7 & Applying disciplinary actions \\
PA8 & Conduct experimental design \\
PA9 & Applying autonomous maintenance \\
PA10 & Calculate the inventory cycle \\
PA11 & Increase the coordination with ware- \\
PA12 & house department \\
\hline \hline
\end{tabular}




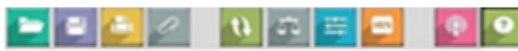

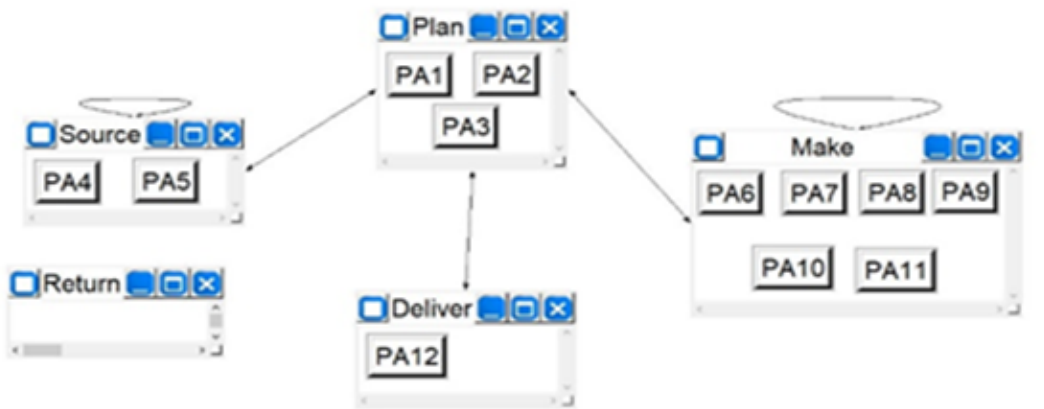

FIGURE 3. ANP model of PT.X

In determining the best priority from the results of risk mitigation in the company, answers are needed from the existing questionnaire. The answer to the questionnaire was using the Super Decision application, obtained through brain storming with the company to determine the best priority of each mitigation. Based on super decision software, there is a normalized by cluster value that shows the percentage of mitigation based on clusters and limiting which shows the overall percentage of mitigation. Based on these two values, prioritized mitigation is to improve coordination with the warehouse (PA3) section and provide optimal safety stock (PA4), other than that based on super decision mitigation software that needs to be eliminated is PA7, which is shortening the engine maintenance period.

\begin{tabular}{|c|c|c|c|c|}
\hline 8 Supe & er Decisions $M$ & d file Q. Pr... - & 口 & \\
\hline & & riorities. & & \\
\hline Icon & Name & $\longdiv { \text { Normalized by Cluster } }$ & er llimiting & \\
\hline No icon & PA1 & 0.12434 & 0.039247 & \\
\hline No kon & PA2 & 0.10337 & 0.032629 & \\
\hline No icon & PA3 & 0.77229 & 0.243771 & \\
\hline No icon & PA4 & 0.59141 & $\longdiv { 0 . 1 5 9 6 4 3 }$ & \\
\hline No kcon & PAS & 0.40859 & 0.110293 & \\
\hline No kon & PA7 & 0.00462 & $\longdiv { 0 . 0 0 1 9 1 6 }$ & \\
\hline No kon & PAB & 0.07973 & 0.033042 & \\
\hline No icon & PAO & 0.10826 & $\longdiv { 0 . 0 4 4 8 6 5 }$ & \\
\hline No icon & PA10 & 0.06313 & $\longdiv { 0 . 0 2 6 1 6 4 }$ & \\
\hline No icon & PA6 & 0.20220 & $\longdiv { 0 . 0 8 3 7 9 6 }$ & \\
\hline No kon & PA11 & 0.13763 & $\longdiv { 0 . 0 5 7 0 3 8 }$ & \\
\hline No kon & PA12 & 0,40442 & 0.167597 & \\
\hline
\end{tabular}

FIGURE 4. Risk mitigation priority results of battery manufacturer

HOR 2 aims to determine preventive actions that must be applied by companies to mitigate risks. Based on the ANP results, 11 preventive actions were obtained to mitigate 11 risk agents where the selected preventive actions were related to obtain the correlation value. 
TABLE 7. Mitigation risk for battery manufacturer

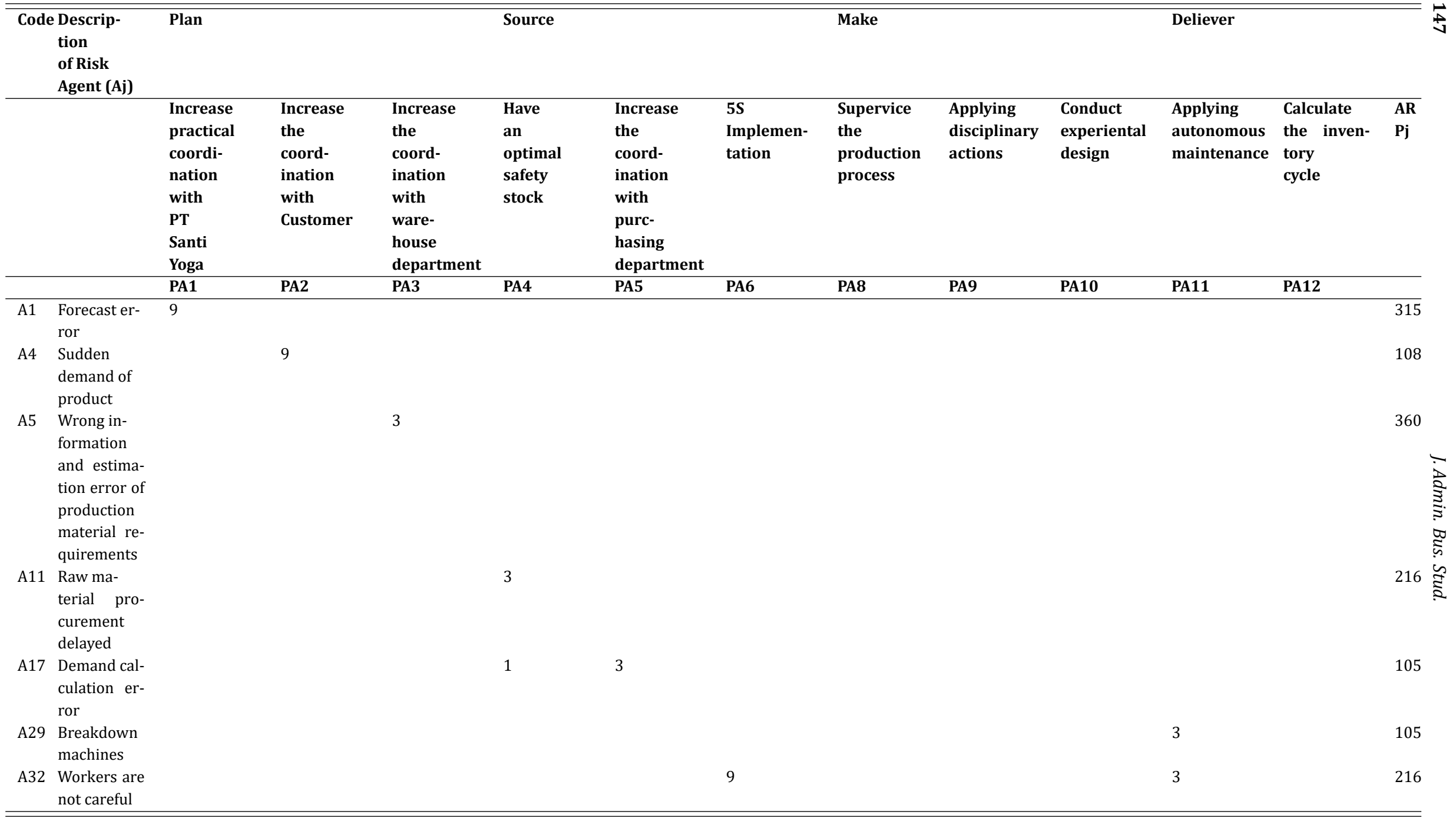


of Risk

Agent (Aj)

\begin{tabular}{|c|c|c|c|c|c|c|c|c|c|c|c|c|c|}
\hline & & $\begin{array}{l}\text { Increase } \\
\text { practical } \\
\text { coordi- } \\
\text { nation } \\
\text { with } \\
\text { PT } \\
\text { Santi } \\
\text { Yoga }\end{array}$ & $\begin{array}{l}\text { Increase } \\
\text { the } \\
\text { coord- } \\
\text { ination } \\
\text { with } \\
\text { Customer }\end{array}$ & $\begin{array}{l}\text { Increase } \\
\text { the } \\
\text { coord- } \\
\text { ination } \\
\text { with } \\
\text { ware- } \\
\text { house } \\
\text { department }\end{array}$ & $\begin{array}{l}\text { Have } \\
\text { an } \\
\text { optimal } \\
\text { safety } \\
\text { stock }\end{array}$ & $\begin{array}{l}\text { Increase } \\
\text { the } \\
\text { coord- } \\
\text { ination } \\
\text { with } \\
\text { purc- } \\
\text { hasing } \\
\text { department }\end{array}$ & $\begin{array}{l}5 S \\
\text { Implemen- } \\
\text { tation }\end{array}$ & $\begin{array}{l}\text { Supervice } \\
\text { the } \\
\text { production } \\
\text { process }\end{array}$ & $\begin{array}{l}\text { Applying } \\
\text { disciplinary } \\
\text { actions }\end{array}$ & $\begin{array}{l}\text { Conduct } \\
\text { experiental } \\
\text { design }\end{array}$ & $\begin{array}{l}\text { Applying } \\
\text { autonomous } \\
\text { maintenance }\end{array}$ & $\begin{array}{l}\text { Calculate } \\
\text { the inven- } \\
\text { tory } \\
\text { cycle }\end{array}$ & $\begin{array}{l}\mathrm{AR} \\
\mathbf{P j}\end{array}$ \\
\hline & & PA1 & PA2 & PA3 & PA4 & PA5 & PA6 & PA8 & PA9 & PA10 & PA11 & PA12 & \\
\hline A33 & $\begin{array}{l}\text { Workers are } \\
\text { not wear } \\
\text { Personal } \\
\text { Protective } \\
\text { Equipment }\end{array}$ & & & & & 9 & & 3 & & & & & 180 \\
\hline A34 & $\begin{array}{l}\text { Workers } \\
\text { violate the } \\
\text { procedures }\end{array}$ & & & & & 9 & & 3 & & & & & 216 \\
\hline A46 & $\begin{array}{l}\text { Production } \\
\text { error }\end{array}$ & & & & & & 3 & & 3 & & & & 216 \\
\hline A60 & $\begin{array}{l}\text { Baterry } \\
\text { voltage } \\
\text { turnover }\end{array}$ & & & & & & & & & & & 3 & 270 \\
\hline & $\begin{array}{l}\text { Total effec- } \\
\text { tiveness of } \\
\text { proactive } \\
\text { action } k \\
\text { (TEk) }\end{array}$ & 2835 & 972 & 1080 & 753 & 315 & 5508 & 648 & 1188 & 648 & 963 & 810 & \\
\hline & $\begin{array}{l}\text { Difficulty of } \\
\text { performing } \\
\text { action } k \\
\text { (Dk) }\end{array}$ & $M(4)$ & $\mathrm{H}(5)$ & L(3) & $\mathrm{M}(4)$ & $\mathrm{L}(3)$ & $\mathrm{L}(3)$ & $\mathrm{L}(3)$ & $\mathrm{L}(3)$ & $\mathrm{H}(5)$ & $\mathrm{L}(3)$ & $\mathrm{M}(4)$ & \\
\hline & $\begin{array}{l}\text { Effective- } \\
\text { ness to } \\
\text { difficulty } \\
\text { ratio of } \\
\text { action } k\end{array}$ & 708.75 & 194.4 & 360 & 188.25 & 105 & 1836 & 216 & 396 & 129.6 & 321 & 202.5 & \\
\hline
\end{tabular}

Rank of

2

8

4

9

11

1

6

3

10

5

7

action $\mathrm{k}$ (Rk) 
The correlation value is multiplied by ARP obtained at HOR 1, to find the Total Effectiveness of Proactive Action. This is to quantitatively measure the effectiveness of risk mitigation measures against risk agents. Each preventive action also weighs the level of difficulty on a small (3), medium (4), and high (5) scale, which shows the level of difficulty of mitigation actions to be carried out in the company. This can be caused by several factors such as costs, time and so on. The value of Total Effectiveness is divided by weighting the difficulty to know the ETD value (effectiveness to difficulty ratio of action) which shows the ratio between the effectiveness of mitigation actions to the level of difficulty. This ETD value will be a reference for the next process and sorted from the highest to the lowest ratio, like HOR 1 . The highest ratio is obtained by the implementation of $5 \mathrm{~S}$ work culture in the company. This shows that the consistency of the work culture in the company must be improved to improve performance in the production system.

$$
\mathbf{T}_{e k}=\Sigma_{i} \mathbf{A R P}_{j} \mathbf{E}_{j k}
$$

Where: $\mathrm{T}_{\mathrm{ek}}=\mathrm{T}_{\text {otal }}$ effectiveness of preventive measures, $\mathrm{ARP}_{j}=$ Aggregate Risk Potential Value, Ejk = Correlation between preventive actions $(\mathrm{k})$ and risk agents $(\mathrm{j})$.

$$
\mathbf{E T D}_{\mathbf{k}}=\mathbf{T E}_{k} / \mathbf{D}_{\mathbf{k}}
$$

Where: $\mathrm{ETD}_{k}=$ Value of total ratio level of difficulty, TEk = Value of total effectiveness of prevention measures, $\mathrm{Dk}=$ Value of the level of difficulty of implementing preventive measures. The following is a table of preventive action results from the three companies that have been sorted by priority.

TABLE 8. Preventive action of battery manufacturer

\begin{tabular}{ll}
\hline \hline Rank & Preventive Action \\
\hline 1 & 5S Implementation \\
2 & Increase practical coordination with distributor company \\
3 & Applying disciplinary actions \\
4 & Increase the coordination with warehouse department \\
5 & Applying autonomous maintenance \\
6 & Supervise the production process \\
7 & Calculate the inventory cycle \\
8 & Increase the coordination with customers \\
9 & Have an optimal safety stock \\
10 & Conduct experimental design \\
11 & Increase the coordinaton with purchasing department \\
\hline \hline
\end{tabular}

TABLE 9. Preventive action of plastic bottle manufacturer

\begin{tabular}{ll}
\hline \hline Rank & Preventive Action \\
\hline 1 & Verify the demand quantity and conduct a demand-forecast \\
2 & Applying on/off job training to all staffs \\
3 & Create an integrated and constructed contract system \\
4 & Have a cross-division coordination in planning production output \\
5 & Choose the best supplier which fits the raw material specification \\
6 & Have a good communication with the supplier \\
7 & Set a proper lead time prior ordering to supplier \\
8 & Choose the best distribution service \\
9 & Designing a proper room which meets the standard \\
10 & Consider the weather forecast prior distribution day \\
11 & Conduct a routine evaluation to all PPIC staffs \\
12 & Specify the criterias related to job assignment \\
13 & Choose a cheaper option in distribution service \\
14 & Negotiate with the supplier related to raw material price \\
15 & Design a proper font and sizing based on visual design charateristic \\
\hline \hline
\end{tabular}




\begin{tabular}{ll}
\hline TABLE 9. & Continue.. \\
\hline \hline Rank & Preventive Action \\
\hline 16 & Re-evaluate before conducting data input \\
17 & Control the purchasing based on company's needs \\
18 & Minimize material inventory \\
19 & Tightened the inpection protocol in warehouse \\
20 & Create a responsive maintenance team in dealing with machine breakdown \\
21 & Conduct a training related to operation activites to all staffs in production floor \\
22 & Conduct a legal approach if the suppliers broke the terms and rules \\
23 & Give an adequate break time to all staffs \\
24 & Rework all returned-defective products and increase the performance of final product \\
\hline
\end{tabular}

TABLE 10. Preventive action of industrial gear manufacturer

\begin{tabular}{ll}
\hline \hline Rank & Preventive Action \\
\hline 1 & Have a routine training protocol \\
2 & Conduct a performance appraisal to all staffs \\
\hline \hline
\end{tabular}

At PT X the highest ratio was shown by the implementation of $5 \mathrm{~S}$ work culture in the company. This shows that the consistency of the work culture in the company must be improved to improve performance in the production system. In mitigating PA 6, namely implementing 5S. 5S itself is one of the concepts of the existing lean manufacturing system, $5 \mathrm{~S}$ itself consists of seiri which means removing items that are not used in the work environment, seiton provides a standard for storing and placing goods in its place, seiso which is maintaining the cleanliness of the workplace, seiketsu ie maintain a work environment that remains neat, and shitsuke namely discipline in applying $5 \mathrm{~S}$ yourself. From every $5 \mathrm{~S}$ this is the most important to be implemented by battery manufacturer is seiketsu and shitsuke. Workers need to maintain a workplace environment that remains neat and clean so as to reduce unnecessary work in the production process on the production floor and discipline in applying $5 \mathrm{~S}$ so as not to disturb workers or concentrate themselves while on the production floor and making machines that working in a clean condition so as to reduce machine down due to lack of wakefulness and maintenance.

Based on the final results obtained using matrix HOR 2 for plastic bottle manufacturer which has been sorted again using ANP results shows that the main solution that must be done is PA 18, namely "Ensuring the Amount of Demand and Performing Calculation of Forecasting Production Amount" with ETDk value of 4584.6, thus getting the first rating. Ensuring the number of requests is the main thing that needs to be done by each company so that each amount of production does not experience shortages or excess production when the production process is carried out. In addition to ensuring the number of requests, it is then necessary to do production forecasting so that the production process that is carried out becomes more certain and accurate not only for demand in the near term and for the long term.

At industrial gear manufacturer, the highest mitigation value that must be done by the company is PA12 "Conduct training (Training) regularly. There are 15 regular trainings that have been implemented by the company, including: Moral and ethical training at work, Training in the use of material handling, $\mathrm{K} 3$ and $5 \mathrm{~S}$ training, and others. There is training that is considered important that has not been implemented which has an impact on the risks faced by the company. Such training is like initial training for new employees. This proposal is relevant in accordance with the condition of the company where new employees are not given clear guidance so that employees only follow the path and direction given by their superiors. This causes errors that often occur because the mastery of the knowledge of the employee is not good at doing his job. Therefore, PT $\mathrm{Z}$ requires training or training for new employees both in carrying out the administration of the company to even the details, such as the operation of the machine. By conducting training, it is expected that company risks can be minimized. Between all of the three manufacturer company, there are 1 solution on general that could provide the problems. Based on the studies, the similiar solution is about training. Shown by the batteries manufaturer, placed on the third rank that gives the solution about applying disciplinary actions. Then shown by the plastic bottle manufacturer, placed on the second rank which is apply on/off training to all staffs. The gear 
manufacturer, placed on the first rank which is conducting a training regularly. That could conclude the major problems faced by the three manufacturer companies most of them are training. But on the batteries manufacturer, disciplinary action is similiar to training because disciplinary action could lead into increasing productivity and increasing productivity is one of many purpose of training. In this case the results of risk mitigation that have been obtained from the three manufacturing industries that are the object of research can be stated that each of the same scope of risk will have different causes of risk, all of which are caused by differences in the policies of the company. The results obtained will prove the purpose of this study which is that each company has different risk events, all of which are caused by the diversity of requests faced by each industry and the policies and business processes of each company.

\section{CONCLUSION AND IMPLICATIONS}

- Risk mitigation generated by the three different companies that are tailored to business processes and company policies.

- The three manufacturing industries can be seen from the
SCOR dimension, namely Plan, Sorce, Make, Deliver and Return.

- The risk mitigation results that need to be done for batteray manufacturer with the highest ratio are $5 \mathrm{~S}$ implementation in the company to solve several problems related to the work culture of production floor operators. Based on HOR2, the highest risk ratio mitigation is the implementation of $5 \mathrm{~S}$ in the company to solve several related problems work culture of the production floor operators.

- Risk mitigation that needs to be done at industrial gear manufacturer is to do training training regularly. Training that is proposed and needs to be implemented in the company is special training or training for new employees.

- For plastic bottle manufacturer based on the results of data processing using the HOR 2 method carried out, it was found that risk mitigation with the highest ratio was "Ensuring the Amount of Demand and Performing the Calculation of Production Number Prediction" to prevent the occurrence of shortages and excess production in the near and long term.

\section{REFERENCES}

Bernik, B., Azis, Y., Kartini, D., \& Harsanto, B. (2015). Managing innovation of SMEs in creative industry for interactive game subsector and TV and Radio subsector based on local wisdom in development of competitiveness business (Case study SMEs in Bandung). International Journal of Business and Administrative Studies, 1(2), 49-53. doi:https://doi.org/ 10.20469/ijbas.10001-2

Darmawi, H. (2008). Risk management. Jakarta, Indonesia: Bumi Aksara.

Gaudenzi, B., \& Borghesi, A. (2006). Managing risks in the supply chain using the AHP method. The International Journal of Logistics Management, 17(1), 114-136. doi:https://doi.org/10.1108/09574090610663464

Ketikidis, P. H., Koh, S. L., Gunasekaran, A., Cucchiella, F., \& Gastaldi, M. (2006). Risk management in supply chain: a real option approach. Journal of Manufacturing Technology Management, 17(6), 700-720. doi:https://doi.org/10.1108/ 17410380610678756

Kleindorfer, P. R., \& Saad, G. H. (2005). Managing disruption risks in supply chains. Production and Operations Management, 14(1), 53-68. doi:https://doi.org/10.1111/j.1937-5956.2005.tb00009.x

Kull, T., \& Closs, D. (2008). The risk of second-tier supplier failures in serial supply chains: Implications for order policies and distributor autonomy. European Journal of Operational Research, 186(3), 1158-1174. doi:https://doi.org/10.1016/ j.ejor.2007.02.028

Norrman, A., \& Jansson, U. (2004). Ericsson's proactive supply chain risk management approach after a serious sub-supplier accident. International Journal of Physical Distribution \& Logistics Management, 34(5), 434-456. doi:https://doi.org/ 10.1108/09600030410545463

Phungphol, W., Tumad, S., Sangnin, K., \& Pooripakdee, S. (2018). Creating passion for preparedness of automotive industry entrepreneurs for industry 4.0 era in the southern part of thailand. International Journal of Business and Economic Affairs, 3(1). doi:https://doi.org/10.24088/ijbea-2018-31001

Piyachat, B. (2017). The relationships among resources' commitment reverse logistics innovation reverse logistics performance and reverse logistics cost savings: Manufacturing vs service industry. Journal of Administrative and Business Studies, 3(3), 122-135. doi:https://doi.org/10.20474/jabs-3.3.2 
Pujawan, I. N., \& Geraldin, L. H. (2009). House of risk: A model for proactive supply chain risk management. Business Process Management Journal, 15(6), 953-967. doi:https://doi.org/10.1108/14637150911003801

Pujawan, I. N., \& Mahendrawathi, L. (2010). Supply chain management. Surabaya, Indonesia: Guna Widya.

Rizqiah, E. (2017). Manajemen supply chain dengan mempertimbangkan kepentingan stakeholder pada industri gula (Unpublished master's thesis). Institut Teknologi Sepuluh November, Surabaya, Indonesia.

Saaty, T. L. (1996). Decision making with dependence and feedback the analytic network process. Pittsburgh, PA: RWS Publications.

Sinha, P. R., Whitman, L. E., \& Malzahn, D. (2004). Methodology to mitigate supplier risk in an aerospace supply chain. Supply Chain Management: An International Journal, 9(2), 154-168. doi:https://doi.org/10.1108/13598540410527051

Tang, C. S. (2006). Robust strategies for mitigating supply chain disruptions. International Journal of Logistics: Research and Applications, 9(1), 33-45. doi:https://doi.org/10.1080/13675560500405584

Waters, D. (2011). Supply chain risk management: Vulnerability and resilience in logistics. London, UK: Kogan Page Publishers.

Wibisono, G. (2006). Performance management, concepts, design, and engineering increase company competitiveness. Jakarta, Indonesia: Erlangga. 